\title{
Large Uncertainty on Forest Area Change in the Early 21st Century among Widely Used Global Land Cover Datasets
}

\author{
He Chen ${ }^{1,2}$, Zhenzhong Zeng ${ }^{2, *}$, Jie Wu ${ }^{2}$, Liqing Peng ${ }^{3}$, Venkataraman Lakshmi ${ }^{4}$, Hong Yang ${ }^{5}$ \\ and Junguo Liu ${ }^{2}$ \\ 1 School of Environment, Harbin Institute of Technology, Harbin 150001, China; 11849584@mail.sustech.edu.cn \\ 2 School of Environmental Science and Engineering, Southern University of Science and Technology, \\ Shenzhen 518055, China; wuj6@mail.sustech.edu.cn (J.W.); liujg@sustech.edu.cn (J.L.) \\ 3 World Resources Institute, Washington, DC 20002, USA; lpeng@princeton.edu \\ 4 Department of Engineering Systems and Environment, University of Virginia, \\ Charlottesville, VA 22904, USA; vlakshmi@virginia.edu \\ 5 Department of Systems Analysis, Integrated Assessment and Modelling, Swiss Federal Institute for Aquatic \\ Science and Technology (Eawag), 8600 Dübendorf, Switzerland; Hong.Yang@eawag.ch \\ * Correspondence: zengzz@sustech.edu.cn
}

Received: 25 September 2020; Accepted: 23 October 2020; Published: 25 October 2020

\begin{abstract}
Forests play an important role in the Earth's system. Understanding the states and changes in global forests is vital for ecological assessments and forest policy guidance. However, there is no consensus on how global forests have changed based on current datasets. In this study, five global land cover datasets and Global Forest Resources Assessments (FRA) were assessed to reveal uncertainties in the global forest changes in the early $21^{\text {st }}$ century. These datasets displayed substantial divergences in total area, spatial distribution, latitudinal profile, and annual area change from 2001 to 2012. These datasets also display completely divergent conclusions on forest area changes for different countries. Among the datasets, total forest area changes range from an increase of $1.7 \times 10^{6} \mathrm{~km}^{2}$ to a decrease of $1.6 \times 10^{6} \mathrm{~km}^{2}$. All the datasets show deforestation in the tropics. The accuracies of the datasets in detecting forest cover changes were evaluated by a global land cover validation dataset. The spatial patterns of accuracies are inconsistent among the datasets. This study calls for the development of a more accurate database to support forest policies and to contribute to global actions against climate change.
\end{abstract}

Keywords: forest area change; data assessment; uncertainty evaluation; inconsistency

\section{Introduction}

As one of the most widely distributed land cover types, forests have a total area of $40.6 \times 10^{6} \mathrm{~km}^{2}$, which accounts for $31 \%$ of the world's total land area [1]. Forests play an important role in maintaining the balance of the global ecosystem by acting as a carbon sink [2,3], prompting water conservation [4], providing a habitat for species [5], improving landscape functions [6], and regulating the climate [7]. Forests have experienced great changes, including deforestation and afforestation. Understanding states of global forest and its changes help to provide guidelines for forest conservation, protection, and management $[8,9]$.

According to the Food and Agriculture Organization (FAO) of the United Nations (UN), more than $1.29 \times 10^{6} \mathrm{~km}^{2}$ of forest have been lost globally since 1990 [1]. Fires, insects, severe weather events, and ecological evolution are important natural factors that cause changes in forest distribution $[10,11]$. Human activities have significant influence on forests. This includes sourcing wood for industrial and 
fuel usage $[12,13]$. Land expansions caused by human activities, e.g., farmland and urban expansion, are also major causes of deforestation [14]. Such changes can result in significant climate consequences by initiating considerable climate feedbacks in biochemical and biogeophysical processes [7]. For example, the Amazon suffers from the most severe deforestation. As a consequence of the biogeophysical feedback, it has become drier and warmer [15]. Forest changes also affect humans through their ecological functions, such as mitigating the heat island effect [16]. Given that forest changes can greatly affect the Earth systems and human society, it is critical to obtain accurate descriptions of the status and changes of the global forest. However, there is no consensus on how global forests have changed in the past several decades.

There are two main methods to monitor forests at large scales: i.e., remote sensing monitoring and forest censuses. Many global land cover datasets were produced to quantify the global land cover situations and its changes with respect to the advances in remote sensing theory and technology [17]. Large-scale forest monitoring by remote sensing has improved in terms of its availability, accuracy, and spatiotemporal resolution $[18,19]$. These datasets fostered the development of large-scale forest researches $[20,21]$. Forest censuses by governments are another commonly used method to assess forest status. The FAO's FRA reports were the most commonly used national scale forest datasets. It can provide a perspective on the impact of policies and other human factors on forests, e.g., how the Three-North Shelter Forest Program in China significantly improved forest coverage in northern China [22].

Based on existing datasets and studies, global forests have substantially changed, including changes in total area [23], spatial distribution [24], and tree biodiversity [25]. However, these studies came to inconsistent and even contradictory conclusions on global forest changes. Hansen et al. [26] detected global forest change with the Advanced Very High Resolution Radiometer (AVHRR) data, revealing a decrease in the tree cover percentage from 1982 to 1999. Among different regions, Latin America and Southeast Asia were the dominant regions for forest loss. This finding was contradictory to that from the FRA. According to Song et al. [27], global tree cover area increased by $2.2 \times 10^{6} \mathrm{~km}^{2}$ from 1982 to 2016; the gross loss and gain of tree cover both increased, but the rate of tree cover gain was greater than that of tree cover loss, especially after the first decades of the 21st century. In contrast, Hansen et al. [28] reported that global forest area decreased by $1.6 \times 10^{6} \mathrm{~km}^{2}$ from 2001 to 2012 [28]. According to FRA reports, the global forest area decreased by $1.3 \times 10^{6} \mathrm{~km}^{2}$ between 1990 and 2015, including decreases of $7.3 \times 10^{5} \mathrm{~km}^{2}$ from 1990 to 2001 and $5.6 \times 10^{5} \mathrm{~km}^{2}$ from 2001 to 2015 [29-31]. Current studies reached a consensus: the tropics have undergone rapid forest loss over the past several decades. Keenan et al. [23] concluded the tropical forest area decreased by $1.95 \times 10^{6} \mathrm{~km}^{2}$ from 1990 to 2015. Ordway et al. [32] found that agricultural expansion increased forest loss in South America and Southeast Asia; Qin et al. [33] also demonstrated a forest loss in the Brazilian Amazon from 2000 to 2017. Current studies also revealed that cropland expansion was an important driver of the forest loss in the tropics $[24,34]$. However, when it comes to the specific area of forest change, the conclusions are diverse. So far, these studies paid more attention to analyzing the results based on their own datasets, while comparisons between different datasets were often ignored. Comparisons of how forests changed based on the commonly used land cover datasets can help us to understand the states of forest and recognize the inconsistencies among the datasets.

The primary objective of this study was to investigate inconsistencies of global forest changes among five commonly used globally land cover datasets and FRA reports from 2001 to 2012. The selected land cover datasets including Vegetation Continuous Fields (VCF), Global Forest Change (Hansen), Terra and Aqua combined Moderate Resolution Imaging Spectroradiometer Land Cover Climate Modeling Grid (MCD12C1), Land Cover project of the Climate Change Initiative (CCI-LC), and the new generation of Land-Use Harmonization (LUH2). FRA reports also participated in the comparison at country and continental scales. To evaluate the inconsistencies of forest area changes among these datasets, total forest area change, latitudinal profile of forest change, forest area change in different climatic zones, annual area change, and spatial distribution of forest change for the selected datasets 
were compared. The global land cover validation dataset from the United States Geological Survey (USGS) was utilized to evaluate the accuracy of the land cover datasets.

\section{Materials and Methods}

\subsection{Materials}

\subsubsection{VCF}

The Making Earth System Data Records for Use in Research Environments (the MEaSURES) VCF products use a non-parametric trend analysis in each pixel to measure land cover changes [27]. VCF provides the annual global fraction of tree canopy (TC) cover, short vegetation (SV) cover, and bare ground (BG) cover from 1982 to 2016. This dataset is based on the AVHRR and other supplementary data, including Landsat Enhanced Thematic Mapper Plus (ETM+), the Moderate Resolution Imaging Spectroradiometer (MODIS), and other very high-resolution satellite images [27]. This dataset can be obtained from Global Land Analysis and Discovery [35]. In this study, TC was selected to calculate forest area changes from 2001 to 2012 (Table 1).

\subsubsection{Hansen}

Hansen is the high-resolution global maps of twenty-first-century forest cover, including tree canopy data for the year 2000, global forest cover gain between 2000 and 2012, year of gross forest cover loss event, and data mask at $30 \mathrm{~m} \times 30 \mathrm{~m}$ resolution [28,36]. Forest cover gain is displayed as a binary value that provides information on whether forest gain occurred in each pixel from 2000 to 2012 . Hansen also provides information of the years when net forest loss occurred in each pixel. Hansen was produced based on 654,178 growing season Landsat 7 ETM+ images. We used the forest cover gain for 2001-2012, forest cover loss for 2001-2017, and land mask (whether the specific pixel represents land or not) to calculate the global forest area change from 2001 to 2012 (Table 1) [28].

\subsection{3. $\mathrm{MCD} 12 \mathrm{C} 1$}

Version 6 of MCD12C1 product provides land cover data using three land cover classification schemes, i.e., International Geosphere-Biosphere Programme (IGBP), University of Maryland (UMD), and Leaf Area Index (LAI). For each land cover classification scheme, MCD12C1 provides global land cover fraction at a $0.05 \times 0.05^{\circ}$ spatial resolution from 2001 to 2018 . In this study, the IGBP classification scheme was utilized to calculate global forest area changes. Forest cover is defined by the pixels of evergreen broadleaf forest, deciduous needle leaf forest, or deciduous broadleaf forest layers $[37,38]$.

\subsubsection{CCI-LC}

CCI-LC product is produced by the Land Cover (LC) project of the Climate Change Initiative (CCI), which is led by the Europe Space Agency (ESA) [39]. Three original data types were used to develop CCI-LC, including AVHRR data from 1992 to 1999, Systeme Probatoire d'Observation de la Terre-Vegetation (SPOT-VGT) data from 1999 to 2013, and Project for On-Board Autonomy Vegetation (PROBA-V) data for 2013, 2014, and 2015. CCI-LC is at a $300 \mathrm{~m} \times 300 \mathrm{~m}$ resolution, based on the Glob Cover unsupervised classification chain, which utilizes a machine learning algorithm [40]. CCI-LC uses the hierarchical classification system of the United Nations Land Cover Classification System (UN-LCCS), which was developed by the FAO.

\subsubsection{LUH2}

LUH2 is the new generation of global land-use forcing datasets that provide a standard format of historical land use and future projections for climate models. The dataset provides historical reconstructions of land-use, which can be used with future projections via Earth system models. 
LUH2 provides global land-use states and transitions at a $0.25 \times 0.25^{\circ}$ resolution from 850 to 2100 . The classification of LUH2 is more detailed than that of the previous versions (Table 1) [41,42].

Table 1. Basic information of Vegetation Continuous Fields (VCF), Global Forest Change (Hansen), Terra and Aqua combined Moderate Resolution Imaging Spectroradiometer Land Cover Climate Modeling Grid (MCD12C1), Land Cover project of the Climate Change Initiative (CCI-LC), and Land-Use Harmonization (LUH2).

\begin{tabular}{cccccc}
\hline Dataset & $\begin{array}{c}\text { Temporal } \\
\text { Coverage }\end{array}$ & $\begin{array}{c}\text { Temporal } \\
\text { Resolution }\end{array}$ & $\begin{array}{c}\text { Spatial } \\
\text { Resolution }\end{array}$ & $\begin{array}{c}\text { Spatial } \\
\text { Coverage }\end{array}$ & Reference \\
\hline VCF & $1982-2016$ & Yearly & $0.05^{\circ}$ & Global & Song et al., 2018 [27] \\
Hansen & $2001-2017$ & Yearly & $30 \mathrm{~m}$ & Global & Hansen et al., 2013 [28] \\
MCD12C1 & $2001-2017$ & Yearly & $0.05^{\circ}$ & Global & Sulla-Menashe and Friedl, 2018 [38] \\
CCI-LC & $1992-2015$ & Yearly & $300 \mathrm{~m}$ & Global & Bontemps et al., 2013 [40] \\
LUH2 & $850-2100$ & Yearly & $0.25^{\circ}$ & Global & Hurtt et al., 2020 [41] \\
\hline
\end{tabular}

\subsubsection{FRA Reports}

FRA reports are the most comprehensive forest assessment datasets. The dataset provides the global forest resources and their changes every five year. FRA reports are based on country level government inventories and remote sensing data. FRA reports provided every five-year assessment about the global forest resources and their changes. FRA reports were widely used for forest conditions popularizations, policy guidance, and land cover data accuracy validations. FRA report 2000, FRA report 2010, FRA report 2015, and FRA report 2020 were selected to compare in the forest area change with the global land cover datasets at country level.

\subsubsection{USGS Global Land Cover Validation Data}

Global land cover validation data were developed by USGS based on high resolution commercial satellite imagery. Over 1100 individual scenes of commercial data imagery were utilized to produce the validation data from several satellites, including QuickBird, WorldView-1, WorldView-2, IKONOS, OrbView-3, and GeoEye-1. The USGS validation dataset, includes $5005 \mathrm{~km} \times 5 \mathrm{~km}$ samples at a global scale, with samples locations that were randomly selected based on the modified Köppen climate zones and population $[43,44]$. The validation dataset provides the dominant land cover type in each pixel at a $2 \mathrm{~m}$ spatial resolution, spanning 2001-2014.

\subsection{Data Processing}

To ensure that the global land cover datasets at different temporal and spatial scales (VCF, Hansen, MCD12C1, CCI-LC, and LUH2) are comparable, all of the land cover datasets were aggregated to the same temporal period, spatial resolution, and spatial coverage. As Hansen exhibits the least latitude coverage $\left(80^{\circ} \mathrm{N}-60^{\circ} \mathrm{S}\right)$ and shortest temporal period (2001-2012) among the five land cover datasets, all of the datasets were adjusted to the same spatiotemporal extent (latitude: $80^{\circ} \mathrm{N}-60^{\circ} \mathrm{S}$; time period: 2001-2012). We also processed all the five datasets at a $0.05^{\circ}$ resolution following the procedures outlined below.

Hansen provides information on when forest loss occurred from 2001 to 2017 and whether forest gain occurred between 2001 and 2012 in each $30 \mathrm{~m} \times 30 \mathrm{~m}$ pixel. The number of pixels of forest loss, forest gain, and the land pixel in every $200 \times 200$ Hansen block (matched to a $0.05 \times 0.05^{\circ}$ pixel) were calculated. The forest change ratio in a $0.05 \times 0.05^{\circ}$ pixel was calculated by dividing the number of net change pixels (the number of forest gain pixels minus the number of forest loss pixels) by the total number of land pixels:

$$
\text { Change ratio }_{[i, j]}=\frac{\text { num }_{\text {gain }}-\text { num }_{\text {loss }}}{\text { num }_{\text {land }}} \text {, }
$$


where $i$ and $j$ refers to the row number and column number of the $0.05 \times 0.05^{\circ}$ pixel; $n u m_{\text {gain }}$ refers to the number of forest gain in the pixel $[i, j] ; n_{\text {um }}$ loss refers to the number of forest loss event range from

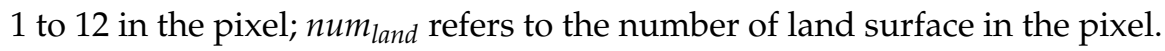

CCI-LC provides the land cover types in each $250 \mathrm{~m} \times 250 \mathrm{~m}$ pixel. In this study, regions with the class code $30,40,50,60,70,80,90$, and 100 were defined as forest areas based on the legend system. We counted the pixel number of the above layers as forest cover in every $18 \times 18$ CCI-LC block (matched to a $0.05 \times 0.05^{\circ}$ pixel), representing the forest cover ratio in each $0.05^{\circ}$ pixel.

Forest cover ratio of VCF was obtained from the Percent Tree Cover layer. For the MCD12C1, evergreen needle leaf forest, evergreen broadleaf forest, deciduous needle leaf forest, and deciduous broadleaf forest land cover types were selected as forest cover under Land_Cover_Type_1_Percent for the IGBP scheme. For LUH2, the variables of primf (forested primary land) and secdf (potentially forested secondary land) in the states layer were selected to obtain the percentage of forest cover in each pixel. For these three datasets, forest area change in each pixel was calculated by multiplying the forest cover percentage by the area of the pixel.

To assess the accuracy of the land cover datasets, the forest cover percentage of each sample was calculated. First, we transformed the projection of the global land cover validation data from Universal Transverse Mercator (UTM) Projection to latitude and longitude. Second, the corresponding row number and column number for each sample were calculated based on the latitude and longitude. Then the numbers of forest pixel in each sample were calculated. The forest cover percentage in the sample is equal to the pixel numbers of forest divided by the total pixel numbers in the sample. We only found date information for 300 samples out of the 500 samples, such that the accuracy validation was based on the 300 samples with date information.

We also compared the forest area changes at country level. We calculated the forest area for the years 2001 and 2012 for each country; forest area change for each country was calculated by subtracting forest area of 2001 from that of 2012.

\subsection{Statistical Indicators}

To understand the spatial distribution of forest area changes for the five land cover datasets, we calculated the standard deviation and deviation among the five land cover datasets to describe the magnitude of the difference. For pixel $[i, j]$, the standard deviation and deviation were defined as follows:

$$
\begin{gathered}
\text { Standard deviation }_{[i, j]}=\sqrt{\frac{\sum_{k=1}^{5}\left(x_{i, j, k}-\bar{x}_{i, j}\right)^{2}}{5}}, \\
\operatorname{Deviation}_{[i, j]}=\frac{\sum_{k=1}^{5}\left|x_{i, j, k}-\bar{x}_{i, j}\right|}{5},
\end{gathered}
$$

where $i$ and $j$ refers to the row number and column number, respectively; $x_{i, j, k}$ refers to the forest area change for pixel $[i, j]$ of dataset $k ; \bar{x}_{i, j}$ refers to the average of forest area change in the five land cover datasets for pixel $[i, j]$.

\section{Results}

\subsection{Total Forest Area Change from 2001 to 2012}

There was substantial inconsistency in total global forest area change among the five global land cover datasets. Figure 1 displays the total forest area change from 2001 to 2012 in $80^{\circ} \mathrm{N}-60^{\circ} \mathrm{S}$ for the five land cover datasets and FRA reports. The VCF was the only dataset that displayed an increase in forest area $\left(1.7 \times 10^{6} \mathrm{~km}^{2}\right)$. Hansen exhibited the largest forest area decrease, up to $1.6 \times 10^{6} \mathrm{~km}^{2}$, followed by the forest losses of $0.4 \times 10^{6} \mathrm{~km}^{2}$ for MCD12C1, $0.2 \times 10^{6} \mathrm{~km}^{2}$ for CCI-LC, and $0.1 \times 10^{6} \mathrm{~km}^{2}$ for the LUH2. The gap in the forest area change between VCF and Hansen was $3.3 \times 10^{6} \mathrm{~km}^{2}$, accounting for $8.8 \%$ of the total forest area worldwide $\left(4.1 \times 10^{7} \mathrm{~km}^{2}\right)$ based on FRA report 2015 [31]. 


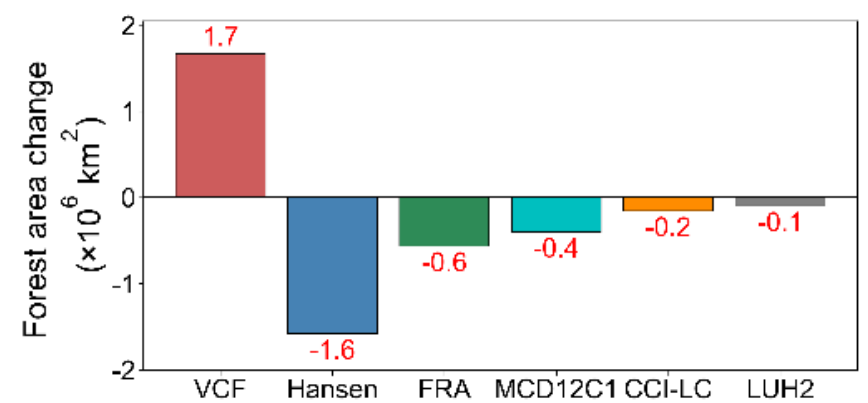

Figure 1. Total forest area changes in $60^{\circ} \mathrm{S}-80^{\circ} \mathrm{N}$ for VCF, Hansen, MCD12C1, CCI-LC, and LUH2 from 2001 to 2012.

Forest area changes across climatic zones are displayed in Figure 2. In the boreal zone $\left(66.5^{\circ} \mathrm{N}-80.0^{\circ} \mathrm{N}\right.$ in this study), VCF, FRA, and CCI-LC displayed increases in forest area, while the other datasets demonstrated decreases. VCF indicated the largest forest area increase $\left(2.2 \times 10^{5} \mathrm{~km}^{2}\right)$ (Figure 2a). In the temperate zone $\left(35^{\circ} \mathrm{N}-66.5^{\circ} \mathrm{N}\right.$ and $\left.35^{\circ} \mathrm{S}-60^{\circ} \mathrm{S}\right)$ (Figure $2 \mathrm{~b}$ ), Hansen indicated forest loss while other datasets indicated forest gain. Among them, VCF indicated the largest forest gain, followed by FRA. In the sub tropics, VCF indicated the largest forest gain $\left(1.9 \times 10^{5} \mathrm{~km}^{2}\right)$, and Hansen indicated the largest forest loss $\left(1.5 \times 10^{5} \mathrm{~km}^{2}\right)$. As for the tropics $\left(23.5^{\circ} \mathrm{S}-23.5^{\circ} \mathrm{N}\right)$, all the datasets indicated forest loss. FRA reported the largest forest loss area $\left(10.0 \times 10^{5} \mathrm{~km}^{2}\right)$, which approximately seven times that of VCF $\left(1.2 \times 10^{5} \mathrm{~km}^{2}\right)$. Hansen also indicated a large forest loss $\left(8.5 \times 10^{5} \mathrm{~km}^{2}\right)$. The tropics was the only climatic zone where all the datasets indicated a same trend (decrease) in forest change. This conclusion was consistent with previous studies: Hansen et al. [45] quantified the gross forest cover loss in the tropics as $47.6 \times 10^{4} \mathrm{~km}^{2}$ from 2000 to 2005, and Zeng et al. [24] found that there was a rapid forest loss in Southeast Asia in the early 21st century (about $29.3 \times 10^{4} \mathrm{~km}^{2}$ ). In general, VCF displayed increases in forest area in the boreal, temperate, and subtropical zones; it also indicated the least forest gain in the tropics. Hansen reported the largest forest loss among these datasets for all climatic zones except for the tropics.
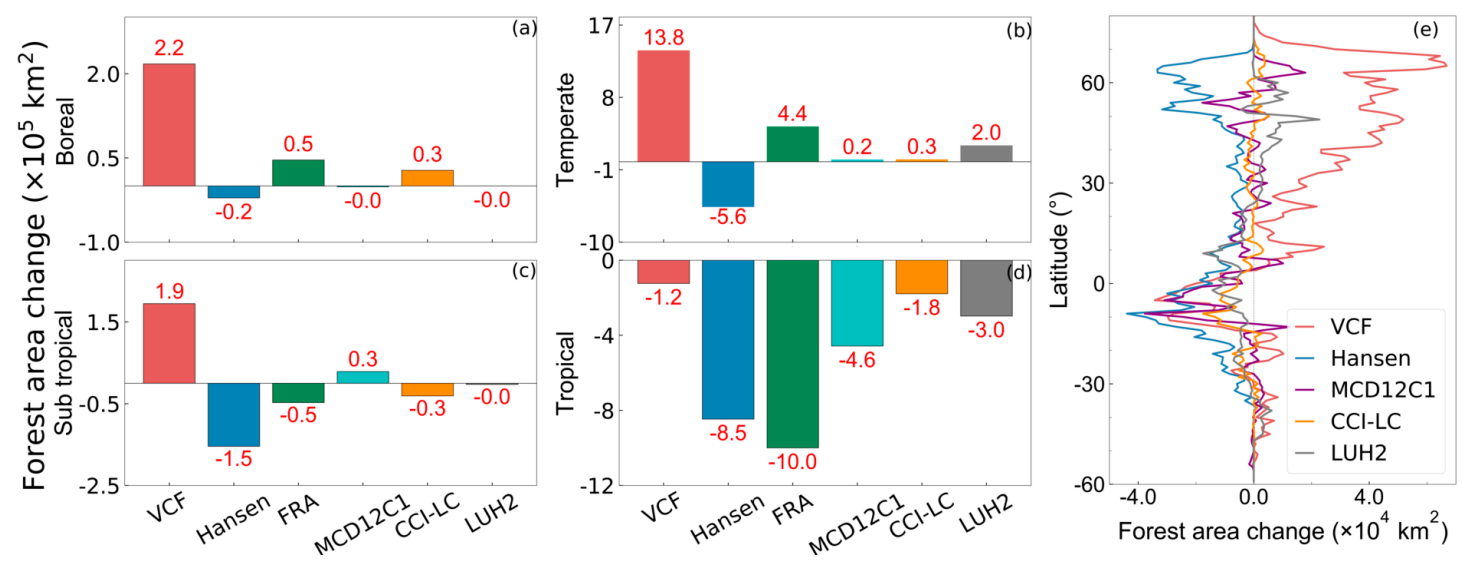

Figure 2. Forest area change in different climatic zones from 2001 to 2012 : (a) boreal $\left(66.5^{\circ} \mathrm{N}-80^{\circ} \mathrm{N}\right)$, (b) temperate $\left(35^{\circ} \mathrm{N}-66.5^{\circ} \mathrm{N}\right.$ and $\left.35^{\circ} \mathrm{S}-60^{\circ} \mathrm{S}\right)$, (c) subtropical $\left(23.5^{\circ} \mathrm{N}-35^{\circ} \mathrm{N}\right.$ and $\left.23.5^{\circ} \mathrm{S}-35^{\circ} \mathrm{S}\right)$, (d) tropical $\left(23.5^{\circ} \mathrm{S}-23.5^{\circ} \mathrm{N}\right)$, and $(\mathbf{e})$ the latitudinal profiles of forest area change in $60^{\circ} \mathrm{S}-80^{\circ} \mathrm{N}$.

We also compared the latitudinal profiles of forest area changes based on the five datasets. In Figure 2e, VCF exhibited forest area gains in the northern hemisphere and the southern temperate zone but identified forest losses in the tropics and the southern hemisphere. VCF also had the largest latitudinal average in forest area change. Hansen showed gross forest loss along the latitudes. The latitudinal profiles of forest area changes for MCD12C1, CCI-LC, and LUH2 fluctuated with latitude, but all the three datasets indicated overall forest losses. Most of the inconsistencies occurred 
in the northern hemisphere, where all the datasets demonstrated decreases in the $10^{\circ} \mathrm{S}-10^{\circ} \mathrm{N}$ latitudinal range, which corresponds to the Amazon and Southeast Asia. The difference in the latitudinal profile of forest area change between VCF and Hansen was the largest, which was consistent with the results displayed in Figure 1.

Forest area changes in different continents were displayed in Figure 3. VCF demonstrated the largest forest gains in Asia, Northern America, Europe, and Oceania. Hansen demonstrated the largest forest losses in Asia, Northern America, Europe, and Oceania. In Africa and South America, regions with severe tropical rainforests, most datasets displayed large forest loss. For other continents, there were inconsistencies in the sign and magnitude of the forest area changes among the datasets.
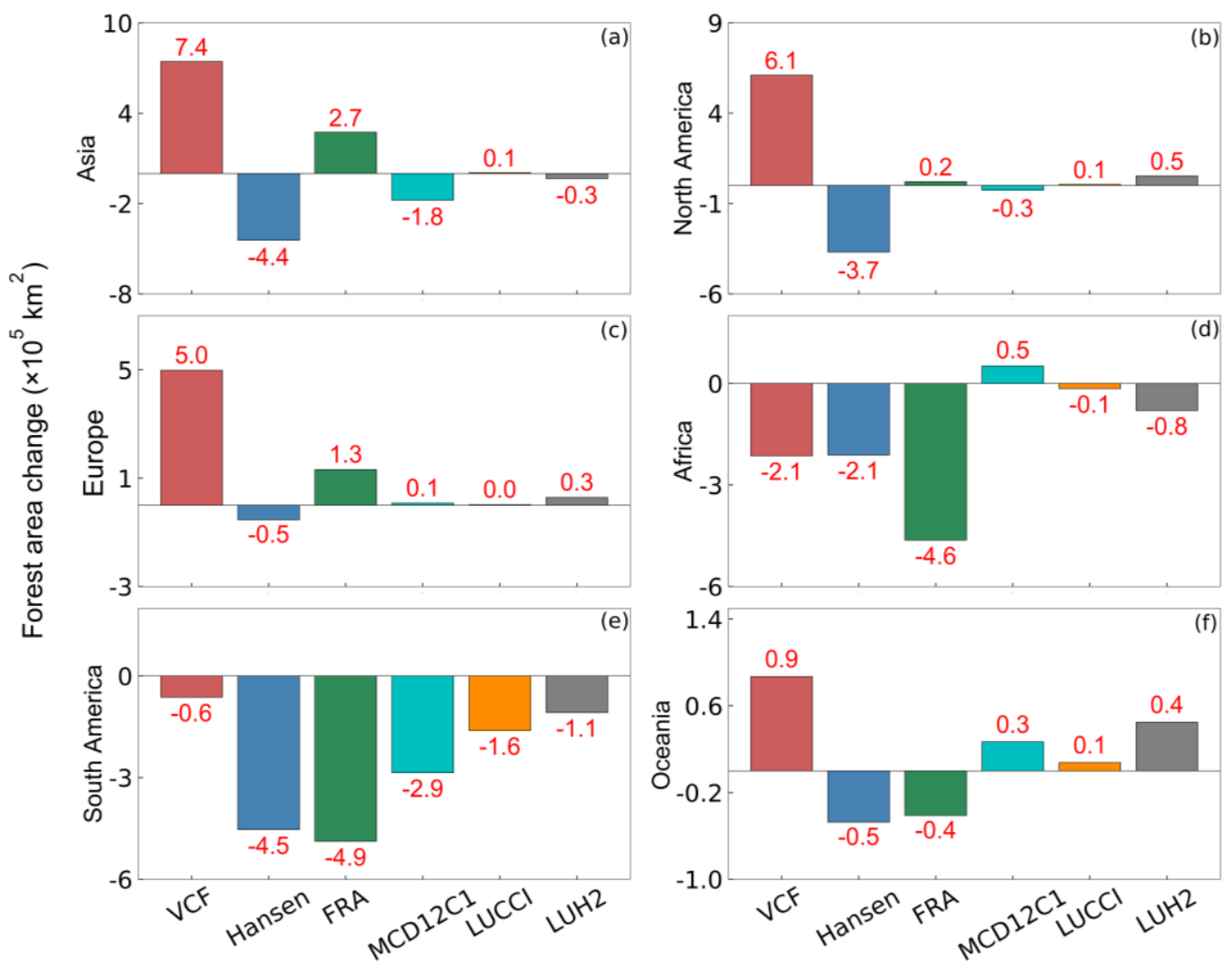

Figure 3. Forest area change in different continents from 2001 to 2012: (a) Asia, (b) North America, (c) Europe, (d) Africa, (e) South America, and (f) Oceania.

\subsection{Spatial Distribution of Forest Change from 2001 to 2012}

Figure 4 displays the spatial distribution of forest area changes in the five land cover datasets. For VCF, forest area increased in Europe, the USA, China, India, and Siberia (Figure 4a). The spatial distribution of Hansen was significantly different from that of VCF. Based on Figure $4 \mathrm{~b}$, the most apparent difference was that Hansen indicated forest losses of in more pixels than that in VCF, especially in Southeast Asia, Congo, and the Amazon. Combining with Figure 4c-e, the magnitudes of forest area changes in MCD12C1, CCI-LC, and LUH2 were much lower than those of VCF and Hansen. Figure $4 \mathrm{f}$ displays the ensemble mean of forest area change in the five land cover datasets. The Congo Rainforest, the Amazon Rainforest, and Southeast Asia displayed severe deforestation, while Eastern China, Siberia, and Eastern USA displayed forest gain. 

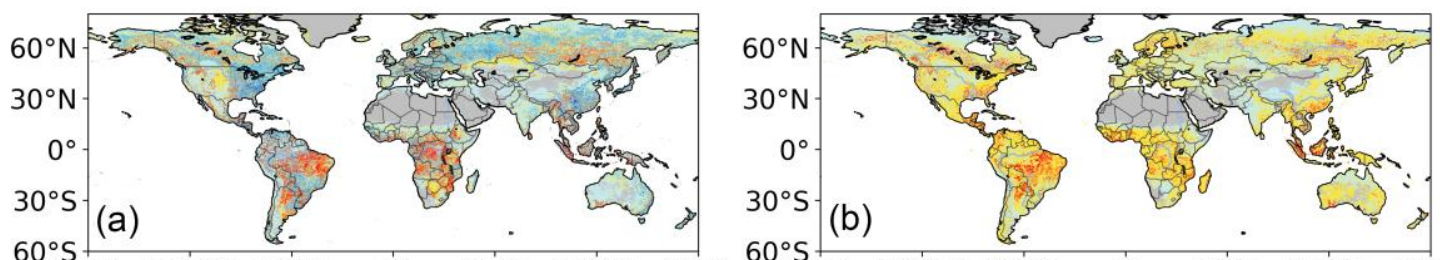

$180^{\circ} 120^{\circ} \mathrm{W} \quad 60^{\circ} \mathrm{W} \quad 0^{\circ} \quad 60^{\circ} \mathrm{E} \quad 120^{\circ} \mathrm{E} \quad 180^{\circ}$ $60^{\circ} \mathrm{S} 80^{\circ} \quad 120^{\circ} \mathrm{W} \quad 60^{\circ} \mathrm{W} \quad 0^{\circ} \quad 60^{\circ} \mathrm{E} \quad 120^{\circ} \mathrm{E} \quad 180^{\circ}$
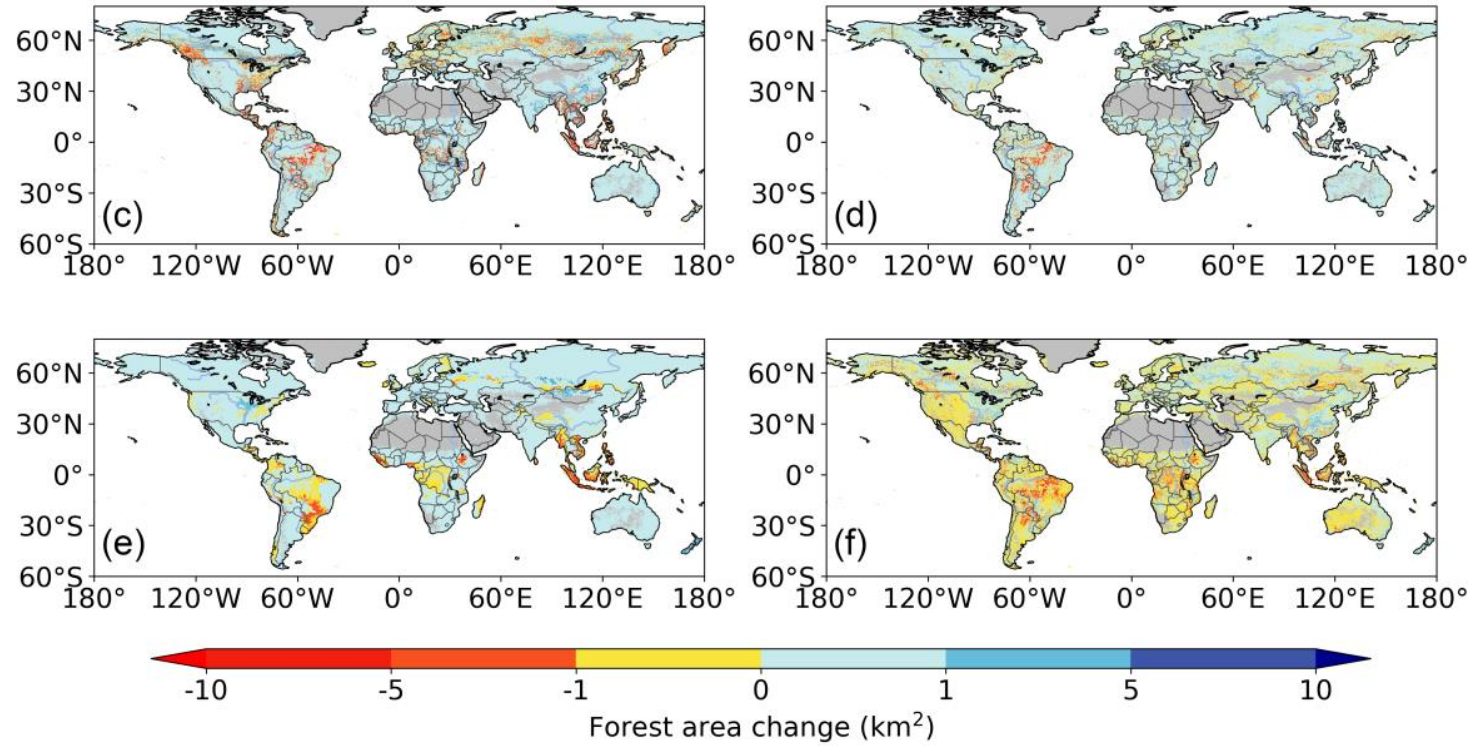

Figure 4. Distributions of forest area changes from 2001 to 2012: (a) VCF, (b) Hansen, (c) MCD12C1, (d) CCI-LC, (e) LUH2, and (f) ensemble mean.

The spatial patterns of standard deviation and deviation of forest area change between the five datasets are demonstrated in Figure 5. Standard deviation and deviation have very similar spatial patterns. The Congo Rainforest, Amazon Rainforest, and Southeast Asia have high standard deviation and deviations, which means discrete distributions of forest change area in these areas. Siberia, India, and Western USA have small standard deviations and deviations in forest area change.

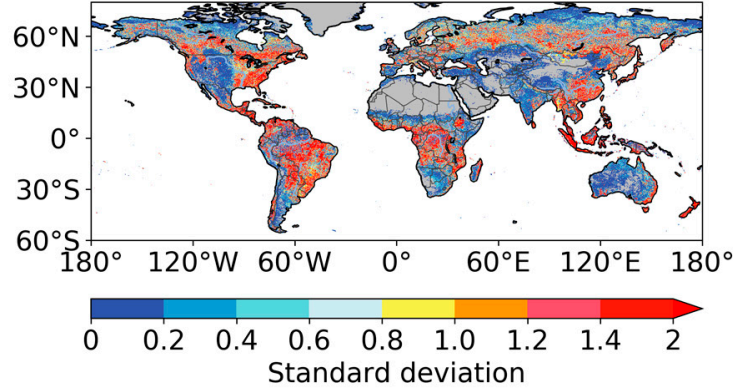

(a)

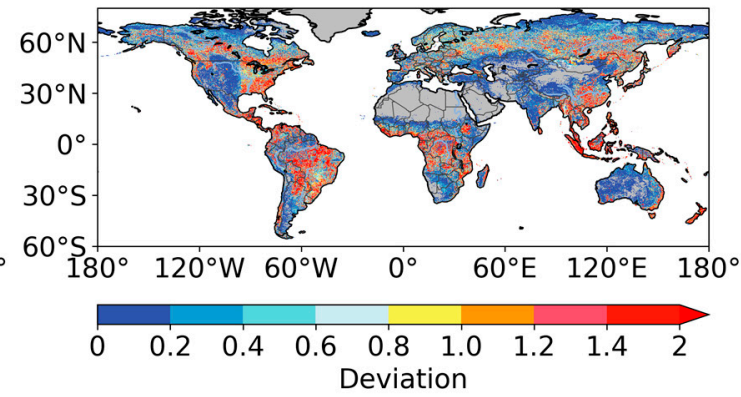

(b)

Figure 5. Distributions of standard deviation and deviation of forest area changes from 2001 to 2012:

(a) standard deviation and (b) deviation.

To assess the inconsistencies of forest area change between VCF and Hansen, which displayed the largest inconsistency, the differences in forest change trends between the two datasets were displayed in Figure 6. Both VCF and Hansen demonstrated forest loss in the Amazon, South Africa, and the majority of Southeast Asia; most of these areas were located in the tropics. In contrast, both VCF and Hansen demonstrated forest gain in Europe, Eastern USA, and Western Siberia. VCF and Hansen 
demonstrated different change trends in forest area in other areas. Several hot spots, where heavy forest changes or large differences occurred in the base map, were also selected to compare differences among the five datasets. The hot spots include North America $\left(37.0^{\circ} \mathrm{N}-50.0^{\circ} \mathrm{N}, 95.0^{\circ} \mathrm{W}-85.0^{\circ} \mathrm{W}\right)$, Europe $\left(45.0^{\circ} \mathrm{N}-54.0^{\circ} \mathrm{N}, 0.0-15.0^{\circ} \mathrm{E}\right)$, Eastern Siberia $\left(55.0^{\circ} \mathrm{N}-66.5^{\circ} \mathrm{N}, 90.0^{\circ} \mathrm{E}-150.0^{\circ} \mathrm{E}\right)$, the Amazon $\left(10.0^{\circ} \mathrm{S}-10.0^{\circ} \mathrm{N}, 73.0^{\circ} \mathrm{W}-40.0^{\circ} \mathrm{W}\right)$, South Africa $\left(5.0^{\circ} \mathrm{S}-8.0^{\circ} \mathrm{N}, 10.0^{\circ} \mathrm{E}-40.0^{\circ} \mathrm{E}\right)$, and Southeast Asia $\left(10.0^{\circ} \mathrm{S}-28.0^{\circ} \mathrm{N}, 92.0-140.0^{\circ} \mathrm{E}\right)$. Apart from the Amazon, where all five datasets displayed forest losses, all other regions demonstrated inconsistent trends in forest change (Figure 6d). Forest losses were clear for regions in the southern hemisphere (e.g., the Amazon and the Congo rainforests), but the uncertainties were larger for regions in the northern hemisphere.

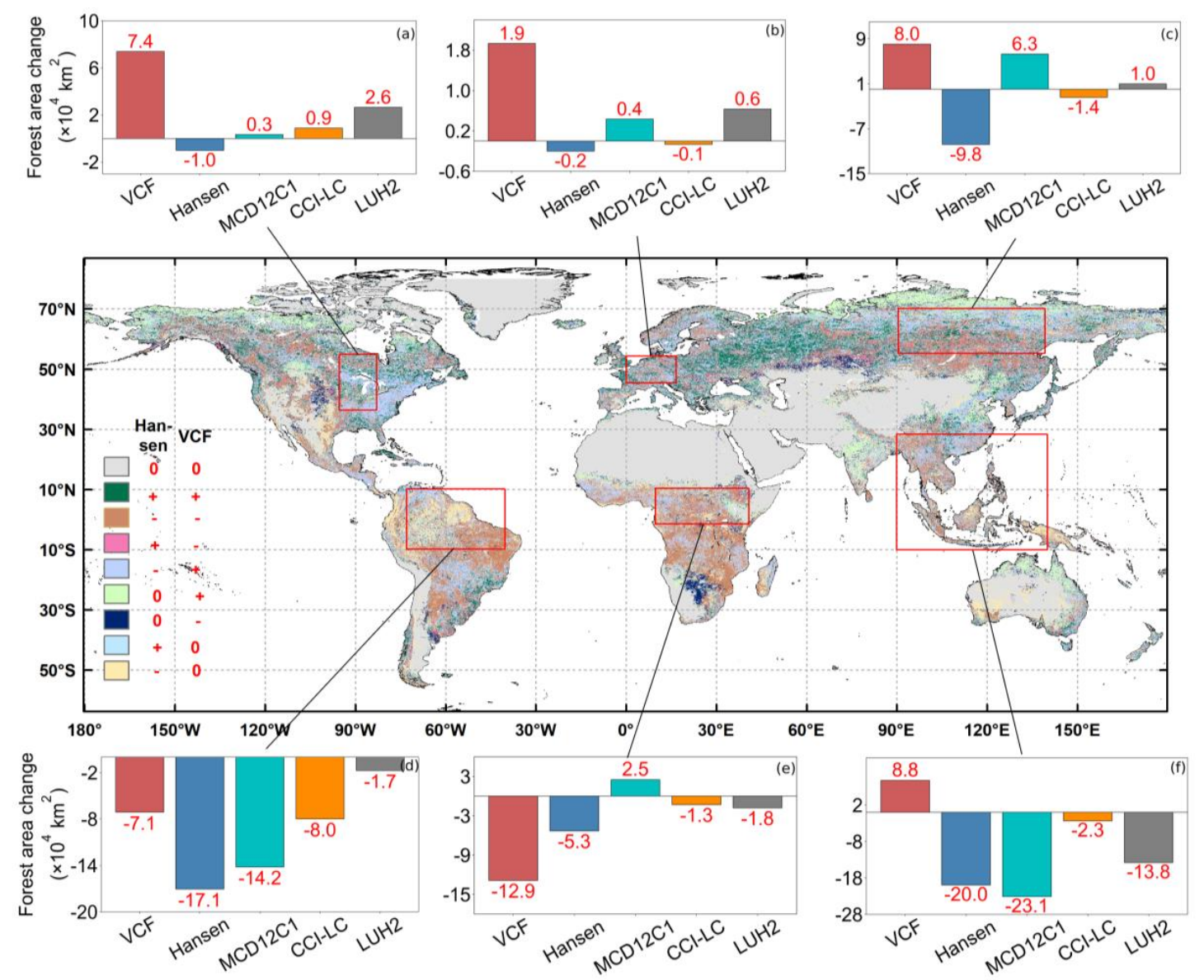

Figure 6. Difference in forest area change between VCF and Hansen, and comparisons of forest area changes among the five datasets in several hotspots. (a) North America $\left(37.0^{\circ} \mathrm{N}-50.0^{\circ} \mathrm{N}, 95.0^{\circ} \mathrm{W}-85.0^{\circ} \mathrm{W}\right)$, (b) Europe $\left(45.0^{\circ} \mathrm{N}-54.0^{\circ} \mathrm{N}, 0.0-15.0^{\circ} \mathrm{E}\right),(\mathrm{c})$ Eastern Siberia $\left(55.0^{\circ} \mathrm{N}-66.5^{\circ} \mathrm{N}, 90.0^{\circ} \mathrm{E}-150.0^{\circ} \mathrm{E}\right),(\mathrm{d})$ Amazon $\left(10.0^{\circ} \mathrm{S}-10.0^{\circ} \mathrm{N}, 73.0^{\circ} \mathrm{W}-40.0^{\circ} \mathrm{W}\right),(\mathbf{e})$ Southern Africa $\left(5.0^{\circ} \mathrm{S}-8.0^{\circ} \mathrm{N}, 10.0^{\circ} \mathrm{E}-40.0^{\circ} \mathrm{E}\right)$, and (f) Southeast Asia $\left(10.0^{\circ} \mathrm{S}-28.0^{\circ} \mathrm{N}, 92.0^{\circ} \mathrm{E}-140.0^{\circ} \mathrm{E}\right)$.

\subsection{Annual Forest Area Change in Five Datasets from 2001 to 2012}

Hansen displayed a relatively stable annual forest area change, while other datasets exhibited irregular changes (Figure 7). Hansen was the only dataset that displayed net forest loss for all years during the research period, and its annual forest loss areas were greater than $5.0 \times 10^{4} \mathrm{~km}^{2}$. The subfigure displayed the magnitude of annual forest area change for these datasets, which represented the range of annual forest area change. VCF had the largest magnitude in forest area change. Forest gain exhibited by VCF was larger than $2.0 \times 10^{6} \mathrm{~km}^{2}$ in 2004; forest loss in 2009 was larger than $1.5 \times 10^{6} \mathrm{~km}^{2}$. The number of deforestation years was greater than the number of afforestation years for VCF. Annual forest area 
changes in MCD12C1, CCI-LC, and LUH2 fluctuated but exhibited a decreasing trends from 2001 to 2012. LUH2 demonstrated a minor total forest area changes with dramatic annual fluctuations in 2009 and 2010.

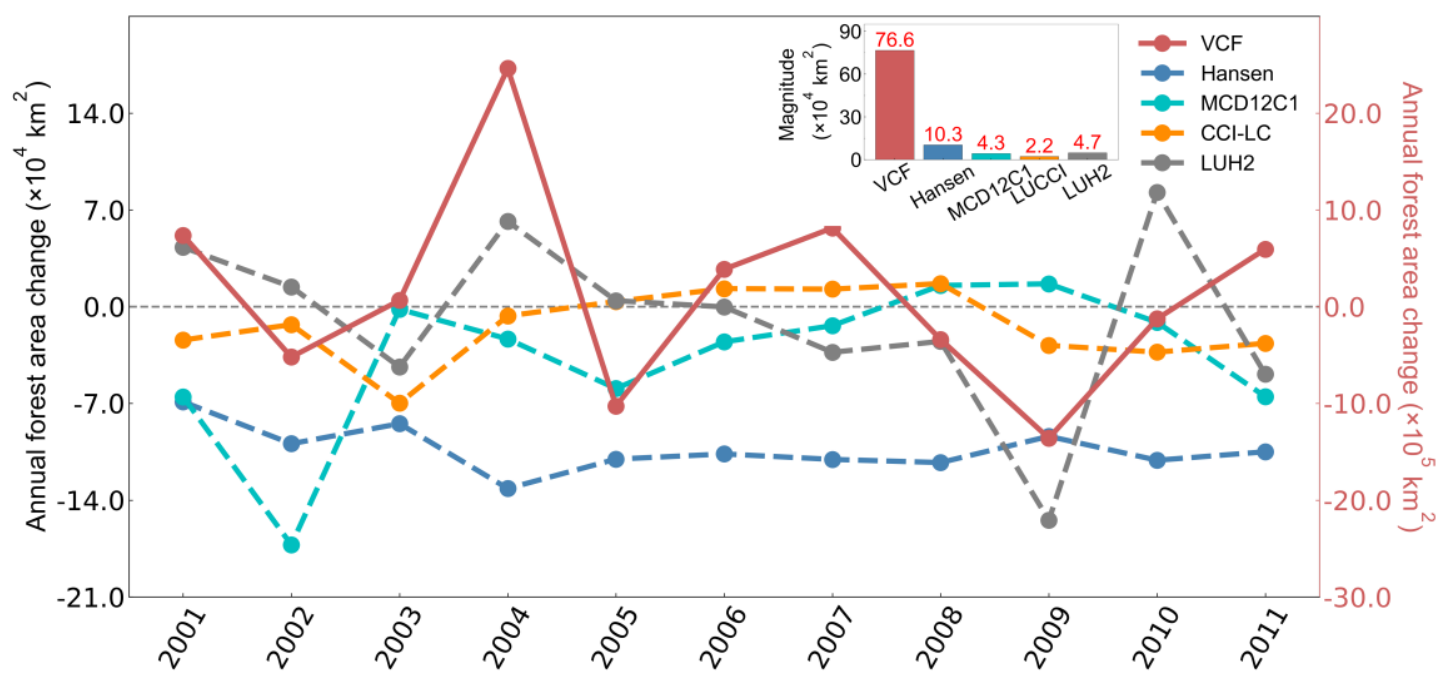

Figure 7. Annual forest area changes in VCF, Hansen, MCD12C1, CCI-LC, and LUH2 from 2001 to 2012.

\subsection{Comparison of Forest Area Change at Country Level}

Forest area changes for these datasets at the country level were calculated. Table 2 lists the forest area changes for countries with land areas over $10.0 \times 10^{7} \mathrm{~km}^{2}$. According to Table 2, the datasets exhibited substantial inconsistencies at the country level. Hansen demonstrated decreases in forest area for all the selected countries. Hansen and FRA indicated very close forest area changes in Brazil, Australia, Kazakhstan, India, and Argentina, but there were huge inconsistencies in other countries. The increased forest area indicated by VCF was the largest among the five datasets. Forest loss was indicated in Brazil and Kazakhstan for VCF. From a country perspective, Hansen demonstrated reductions in Russia and India, while the other datasets exhibited increases in these two countries. All the datasets indicated forest loss in Brazil and Argentina, while they exhibited different patterns of forest changes in other countries.

Table 2. Comparison of forest area changes during 2001-2012 for VCF, Hansen, FRA, MCD12C1, CCI-LC, and LUH2 for nine major countries with total land areas over $10.0 \times 10^{7} \mathrm{~km}^{2}$.

\begin{tabular}{cccccccc}
\hline & & VCF & Hansen & FRA & MCD12C1 & CCI-LC & LUH2 \\
\hline Country & Forest Area $\left(\times \mathbf{1 0}^{\mathbf{4}} \mathbf{~ k m}^{\mathbf{2}}\right)$ & \multicolumn{5}{c}{ Forest Area Change $\left(\times \mathbf{1 0}^{\mathbf{4}} \mathbf{~ k m}^{\mathbf{2}} \mathbf{)}\right.$} \\
\hline Russia & 814.93 & 65.44 & -21.89 & 5.66 & 0.24 & 2.54 & 4.64 \\
Canada & 347.07 & 30.10 & -19.13 & -0.73 & 5.07 & 2.45 & 0.64 \\
USA & 310.10 & 26.88 & -13.24 & 6.56 & -5.19 & -0.97 & 4.67 \\
China & 208.32 & 24.03 & -4.14 & 31.32 & 7.44 & -0.49 & 2.30 \\
Brazil & 493.54 & -11.61 & -29.60 & -27.74 & -19.26 & -9.81 & -8.41 \\
Australia & 124.75 & 6.48 & -4.57 & -4.09 & 2.68 & 0.48 & 1.08 \\
Kazakhstan & 3.31 & -0.43 & -0.06 & -0.06 & -0.29 & 2.08 & -0.03 \\
India & 70.68 & 2.24 & -0.69 & 5.29 & 2.98 & 0.23 & 0.06 \\
Argentina & 27.11 & -4.42 & -4.28 & -4.75 & -0.63 & -3.12 & -0.14 \\
\hline
\end{tabular}




\section{Discussion}

\subsection{Accuracy Assessment Using Global Land Cover Validation}

In this study, five global land cover datasets and FRA reports were evaluated to reveal the inconsistencies in global forest changes from the perspectives of total area, spatial distribution, latitudinal profile, and annual area change from 2001 to 2012. There were huge inconsistencies in global forest changes for the above aspects among the selected datasets. Thus, assessments of data accuracy were essential to understanding the reliabilities of the selected datasets. However, the selected land cover datasets in this study have highly different spatial resolutions (Table 1). Certain very high resolution satellite images (e.g., Google Earth images and QuickBird images) were effective tools to validate several high-resolution datasets (e.g., Hansen data, $30 \mathrm{~m}$ spatial resolution; CCI-LC data, $250 \mathrm{~m}$ spatial resolution) based on visual interpretation [24] but not suitable to validate datasets with lower resolution (e.g., LUH2 data, with a spatial resolution of $0.25 \times 0.25^{\circ}$ ).

Here, the global land cover validation data from USGS was applied to evaluate the accuracies of the selected land cover datasets. Forest cover percentage in each sample was calculated and compared with the forest cover percentages of the land cover datasets (Figure 8). Spatially, underestimation of forest cover percentage commonly occurred in the Amazon, Western USA, and Eastern Europe; on the contrary, overestimation occurred in Eastern Asia, Western Europe, and Northern USA. The correlations between the land cover datasets and the validation data were not very strong: the correlation coefficients were $0.63,0.77,0.59,0.68$, and 0.37 for VCF, Hansen, MCD12C1, CCI-LC, and LUH2, respectively. Hansen had the highest correlation with the validation data, while LUH2 had the lowest correlation. Zeng et al. [24] also proved that Hansen had a pretty good accuracy in Southeast Asia across Google Earth imagery, an overall accuracy of $98.4 \%$ can be achieved. Therefore, Hansen is recommended to be utilized in forest and forest changes estimates.

We note that Hansen provided the forest gain information as a binary value from 2000 to 2012, so that years when forest gain occurred were not available. To calculate forest cover percentage of Hansen, the pixel number of forest gain in the validation pixel $\left(0.05 \times 0.05^{\circ}\right)$ for each year was assumed to be equal in this study. The accuracy of Hansen forest cover percentage based on this hypothesis was lower than the actual accuracy.

\subsection{Possible issues in VCF}

Previous studies have widely reported that the global forest area has decreased over the past several decades $[23,28,31]$. According to FRA reports, the total global forest area in the world was $41.3 \times 10^{6} \mathrm{~km}^{2}, 40.6 \times 10^{6} \mathrm{~km}^{2}, 40.3 \times 10^{6} \mathrm{~km}^{2}, 40.2 \times 10^{6} \mathrm{~km}^{2}$, and $40.0 \times 10^{6} \mathrm{~km}^{2}$ in $1990,2000,2005$, 2010, and 2015, respectively [31]. It is also indicated that the gross forest cover losses in the boreal zone and the temperate zone were $3.5 \times 10^{5} \mathrm{~km}^{2}$ and $1.7 \times 10^{5} \mathrm{~km}^{2}$ from 2000 to 2005 [45]. However, the results based on VCF were contradictory to the general understanding of global forest changes, which indicated an increase in global forest area [27]. VCF revealed an increase of $1.7 \times 10^{6} \mathrm{~km}^{2}$ in total forest area, whereas Hansen, FRA, MCD12C1, CCI_LC, and LUH2 demonstrated decreases of $1.6 \times 10^{6} \mathrm{~km}^{2}, 0.6 \times 10^{6} \mathrm{~km}^{2}, 0.4 \times 10^{6} \mathrm{~km}^{2}, 0.2 \times 10^{6} \mathrm{~km}^{2}$, and $0.1 \times 10^{6} \mathrm{~km}^{2}$, respectively (Figure 1). VCF also exhibited an order of magnitude inter annual forest area change than that in the other land cover datasets. According to these results, inconsistencies among the datasets primarily occurred between VCF and the other datasets. Another implausible behavior of VCF was that its forest area change fluctuated erratically in 2004, 2005, and 2009, indicating the occurrence of rapid forest gains or forest losses (Figure 7). For trees, defined as vegetation taller than $5 \mathrm{~m}$ in VCF, it is unreasonable to expect such a rapid change within a short period. 

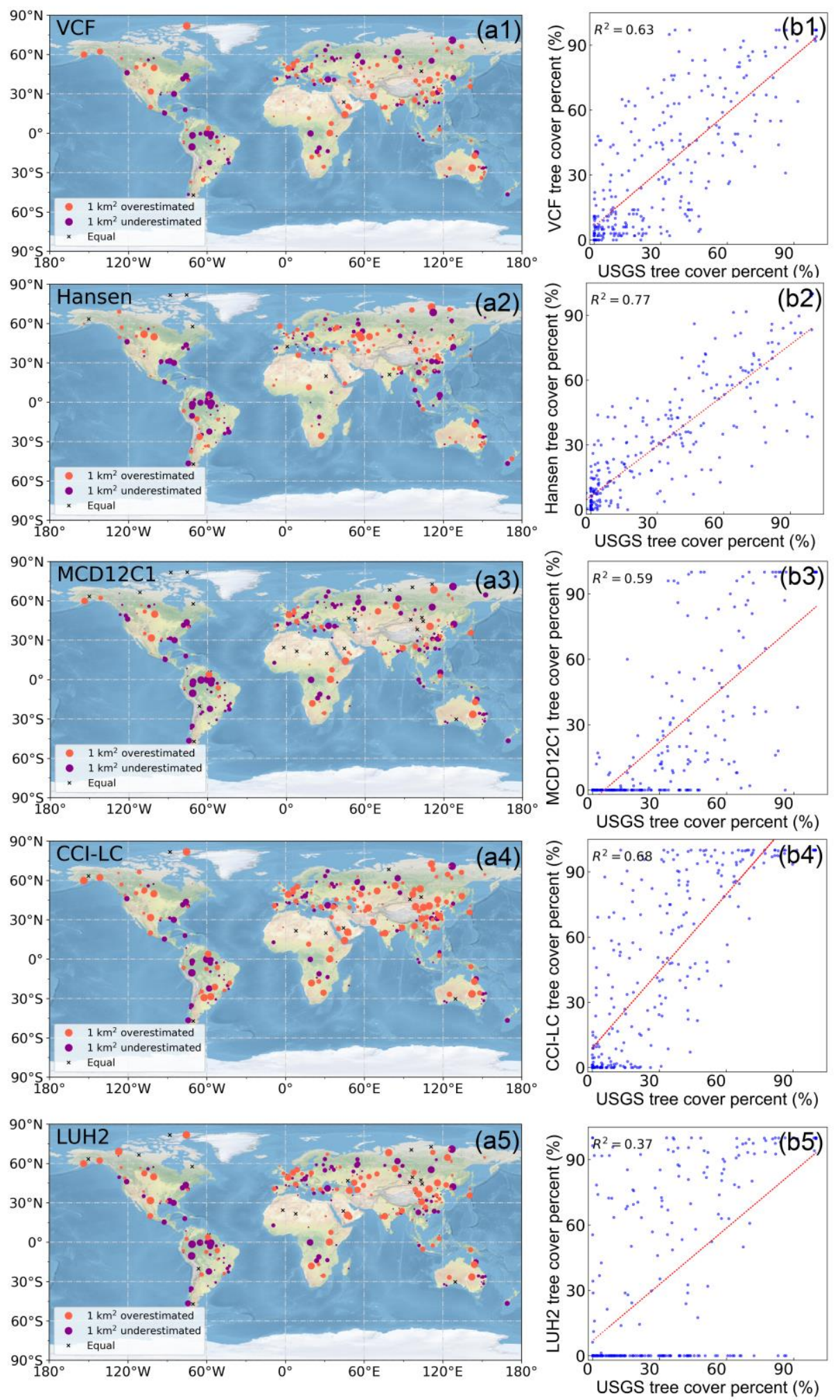

Figure 8. Accuracy assessment of the land cover datasets using USGS's global land cover validation data. Spatial pattern of differences in forest cover percentage between the land cover datasets and global land cover validation data (a1-a5) and correlation coefficient between the land cover datasets and global land cover validation data (b1-b5) for VCF (1), Hansen (2), MCD12C1 (3), CCI-LC (4), and LUH2 (5). Size of dots in (a1-a5) represent the difference of forest cover percentage between the land cover datasets and validation data. 
To evaluate these inconsistencies between VCF and the other land cover datasets, we compared the spatial distributions of forest area changes from VCF with the land cover from MCD12C1 in 2004 and 2005, during which VCF reported drastic fluctuations in forest area. VCF indicated that the forest area increased by $2.4 \times 10^{5} \mathrm{~km}^{2}$ in 2004 (Figure 9a) and decreased by $1.0 \times 10^{5} \mathrm{~km}^{2}$ in 2005 (Figure 9b), but the forest distribution did not substantially change in 2004 and 2005 (Figure 9c or Figure 9d). MCD12C1 demonstrated that the main land cover types in Siberia were grassland and shrub land. Forest area did not change significantly in this region, while VCF displayed clear forest change in the corresponding period. Minor changes in the Amazon forest were indicated by MCD2C1 data, while VCF indicated a noticeable increase in 2004 and a decrease in 2005 for the same area.
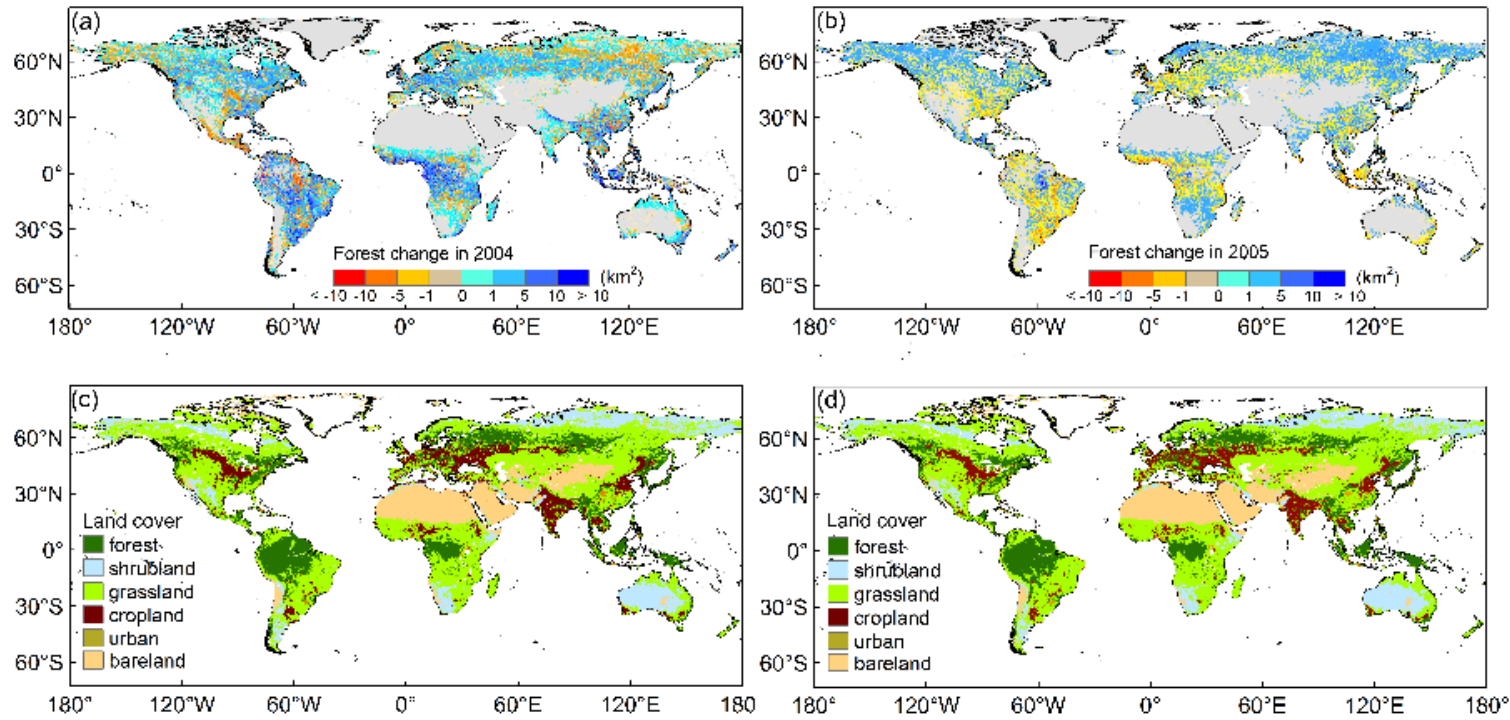

Figure 9. VCF forest area change and MCD12C1 land cover in 2004 and 2005, (a) forest area change in 2004, (b) forest area change in 2005, (c) MCD12C1 land cover in 2004, and (d) MCD12C1 land cover in 2005.

To investigate the rapid forest gain or loss in 2004, 2005, and 2009 indicated by VCF, we utilized the Google Earth images as reference data to validate the reliability of VCF. The fine resolution Google Earth images displayed land surface conditions for a visual inspection of land surface changes. We selected a target pixel in China $\left(110.525^{\circ} \mathrm{E}, 21.775^{\circ} \mathrm{N}\right)$ as an example (the black dot in Figure 10a,b), where VCF reported a large forest increase $(+19.2 \%)$ in 2004 (Figure 10a) and a substantial forest decrease $(-16.6 \%)$ in 2005 (Figure 10b). According to the Google Earth images, short vegetation appeared in 2005, but the tree cover did not change significantly (far less than VCF indicated) (Figure 10c-e). We also validated pixels in Southeast Asia and the US with similar results. The validation indicated that VCF cannot distinguish short vegetation (e.g., crops) from forest cover sufficiently. The seasonal growth of short vegetation, such as crops may be one reason for the inconsistencies between VCF and the other datasets.

\subsection{Impacts of Tree Cover Definition and Land Cover Classification System}

The differences in concepts and definitions of "forest" between different land cover datasets lead to different results in forest detection, forest ranges, and forest transitions [46]. The definitions of "forest" in the selected land cover datasets were different from each other. VCF describes the "tree canopy" as consisting of tall vegetation ( $\geq 5 \mathrm{~m}$ in height) [27]. Hansen defines the tree as all vegetation taller than $5 \mathrm{~m}$ in height [28]. The IGBP classification system in MCD12C1 describes "forest" as land dominated by trees with a percent cover $>60 \%$ and height exceeding $2 \mathrm{~m}$ [38]. CCI-LC defines forest as a parcel or unit of land of at least 0.5 hectares in size that is covered by $10 \%$ or more trees that are $5 \mathrm{~m}$ or taller [39]. FRA defines forest as an area over 0.5 ha with a minimum tree cover of $10 \%$. However, "forest" in FRA reports represents a kind of land use rather than physical trees compared to the satellite-based 
land cover datasets [1]. An area will be classified as forest if it is registered as "forest" land use even if there is no tree. Thus, forest area measurement in different land cover datasets were not consistent. For example, some short shrubs, which are taller than $2 \mathrm{~m}$, but shorter than $5 \mathrm{~m}$, will be counted as forest in MCD12C1 but will not be counted in VCF and Hansen. Besides, different land cover classification systems in land cover datasets also lead to inconsistencies in forest area, and we cannot compare forest area change directly. In addition, for spatial resolution of the land cover datasets, algorithms to identify forest can also lead to inconsistencies in forest change.
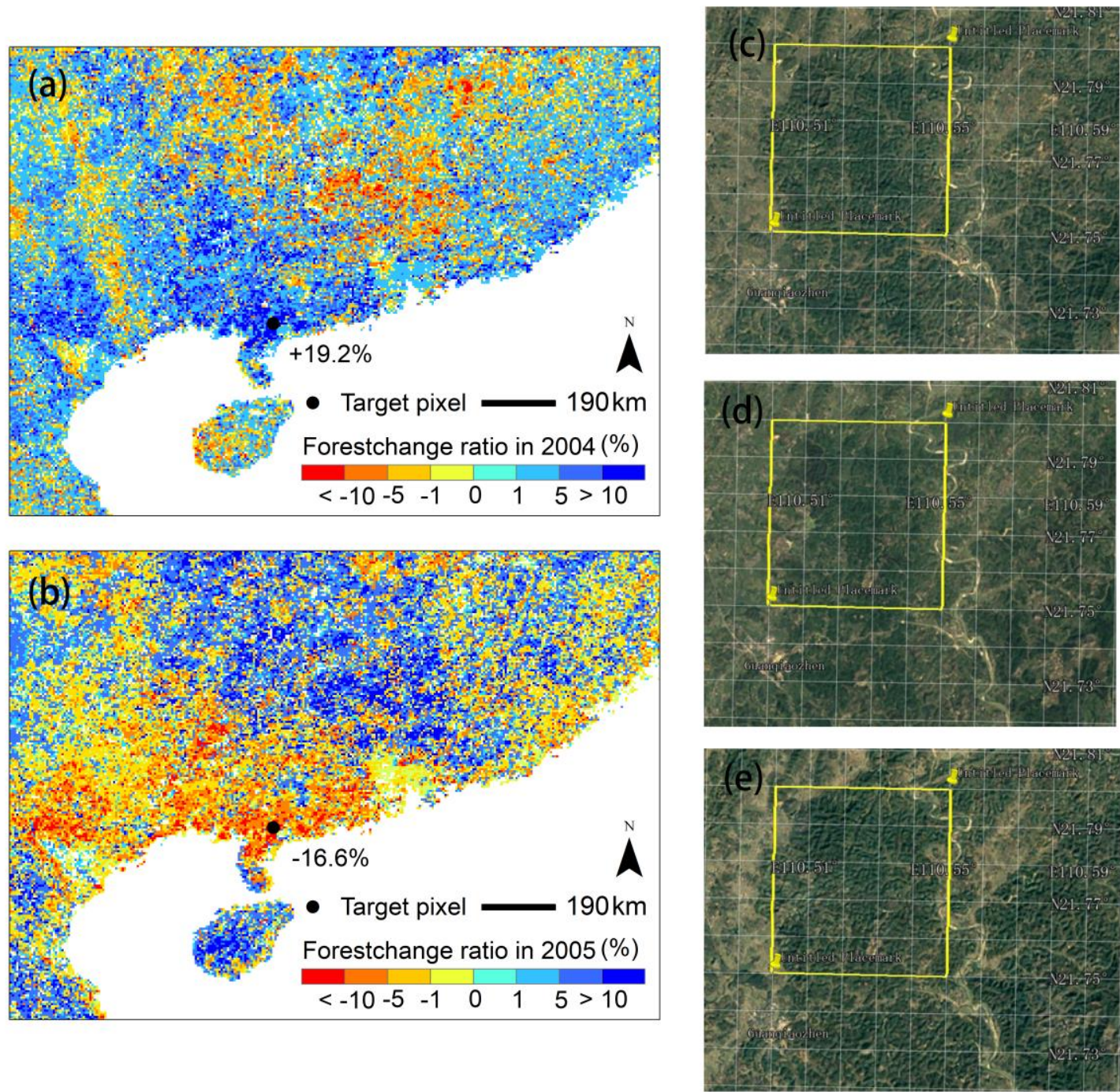

Figure 10. Contrast of forest change between VCF and Google Earth images. (a) VCF forest area change ratio in 2004, (b) VCF forest area change ratio in 2005, (c) land surface of target pixel from Google Earth in December 2004, (d) land surface of target pixel from Google Earth in December 2005, and (e) land surface of target pixel from Google Earth in December 2006.

The inconsistent definition of "forest" was not the major factor for the inconsistencies in the overall global forest area change. VCF and Hansen have the same definition of "forest", but the inconsistencies between them were the largest. VCF displayed the largest forest gain, while Hansen displayed the largest forest loss. So the differences in definition of "forest" were not the decisive factor for the inconsistencies. Another problem for the satellite-based land cover datasets is that they do not assess what happened to the land after deforestation. Regrowth after deforestation is a slow, incremental process compared to deforestation; the latter is easy to spot when comparing satellite 
images. In addition, it is more difficult to identify deforestation from year to year. Identifying regrowth and low shrubs is also challenging. Therefore, there is no clear answer on how global forest area has changed in the early 21st century. We recommend interpreting these datasets with caution and performing detailed local-scale spatial validation before use. We also highly advocate more accurate forest cover data with higher resolution and a better classification system.

\section{Conclusions}

This study analyzed global forest area changes from 2001 to 2012 using five global land cover datasets and FRA reports. To evaluate the inconsistencies in global forest area changes among these datasets, global forest total area change, spatial distribution, latitudinal profile, and annual area change were compared. We found large inconsistencies on forest changes among these datasets. The majority of the datasets indicated decreases in total global forest area, but VCF demonstrated a net increase trend, which was conflicted with the other datasets and previous studies. The inconsistencies in forest changes primarily occurred in the northern hemisphere, while the southern hemisphere showed more consistent results. These datasets demonstrated forest loss in the tropics, but inconsistent forest changes in other zones. Global land cover validation data from USGS was applied to evaluate the accuracies of the land cover datasets. The results indicated that all of the land cover datasets displayed mediocre accuracies in forest cover. Hansen had the highest correlation with validation data, while LUH2 had the lowest correlation. Therefore, Hansen is recommended for forest cover and forest cover change estimations.

The differences in definition of "forest", classification system, spatial resolution, and algorithm can affect the detection of forest and its changes. Due to these differences and the large uncertainties among these datasets, we need to interpret the results based on these land cover datasets with caution. Validations and assessments of forest and its changes using ground-level field data or very high-resolution imagery (e.g., Google Earth or USGS' validation dataset) are needed. In addition, some methods including data fusion and cross-dataset calibration are useful to reconcile the inconsistencies of the differences in forest definition $[47,48]$.

Author Contributions: Conceptualization, Z.Z. and J.L.; methodology, Z.Z.; validation, H.C. and Z.Z.; formal analysis, H.C.; writing — original draft preparation, H.C.; writing—review and editing, Z.Z., J.W., L.P., V.L., H.Y., and J.L.; visualization, H.C. and Z.Z.; supervision, J.L. and Z.Z.; funding acquisition, J.L. and Z.Z. All authors have read and agreed to the published version of the manuscript.

Funding: This study was supported by the Strategic Priority Research Program of the Chinese Academy of Sciences (Grant No. XDA20060402), the National Natural Science Foundation of China (NSFC) (Grant No. 41625001; 42071022), and the start-up fund for Dr. Zeng provided by Southern University of Science and Technology (No. 29/Y01296122).

Acknowledgments: We thank Bruce Pengra from USGS for providing the global land cover dataset.

Conflicts of Interest: The authors declare no conflict of interest.

\section{References}

1. FAO. Global Forest Resources Assessments 2020: Main Report; The Food and Agricultural Organization of the United Nations: Rome, Italy, 2020.

2. Kurz, W.A.; Dymond, C.C.; Stinson, G.; Rampley, G.J.; Neilson, E.T.; Carroll, A.L.; Ebata, T.; Safranyik, L. Mountain pine beetle and forest carbon feedback to climate change. Nature 2008, 452, 987-990. [CrossRef] [PubMed]

3. Seidl, R.; Thom, D.; Kautz, M.; Martin-Benito, D.; Peltoniemi, M.; Vacchiano, G.; Wild, J.; Ascoli, D.; Petr, M.; Honkaniemi, M.P.J.; et al. Forest disturbances under climate change. Nat. Clim. Chang. 2017, 7, 395-402. [CrossRef] [PubMed]

4. Keenan, T.F.; Hollinger, D.Y.; Bohrer, G.; Dragoni, D.; Munger, J.W.; Schmid, H.P.; Richardson, A.D. Increase in forest water-use efficiency as atmospheric carbon dioxide concentrations rise. Nat. Cell Biol. 2013, 499, 324-327. [CrossRef] [PubMed]

5. Williams, S.E.; Marsh, H.; Winter, J. Spatial scale, species diversity, and habitat structure: Small mammals in Australian tropical rain forest. Ecology 2002, 83, 1317-1329. [CrossRef] 
6. McDonnell, M.J.; Pickett, S.T.A. Ecosystem Structure and Function along Urban-Rural Gradients: An Unexploited Opportunity for Ecology. Ecology 1990, 71, 1232-1237. [CrossRef]

7. Bonan, G.B. Forests and Climate Change: Forcings, Feedbacks, and the Climate Benefits of Forests. Science 2008, 320, 1444-1449. [CrossRef]

8. Brack, C. Pollution mitigation and carbon sequestration by an urban forest. Environ. Pollut. 2002, 116, S195-S200. [CrossRef]

9. Nowak, D.J.; Hirabayashi, S.; Bodine, A.; Greenfield, E. Tree and forest effects on air quality and human health in the United States. Environ. Pollut. 2014, 193, 119-129. [CrossRef]

10. North, M.; Stephens, S.L.; Collins, B.M.; Agee, J.K.; Aplet, G.; Franklin, J.F.; Fule, P.Z. Reform forest fire management. Science 2015, 349, 1280-1281. [CrossRef]

11. Pureswaran, D.S.; Roques, A.; Battisti, A. Forest Insects and Climate Change. Curr. For. Rep. 2018, 4, 35-50. [CrossRef]

12. Bethel, J.S.; Schreuder, G.F. Forest Resources: An Overview. Science 1976, 191, 747-752.

13. Zhu, Z.; Piao, S.; Myneni, R.B.; Huang, M.; Zeng, Z.; Canadell, J.G.; Ciais, P.; Sitch, S.; Friedlingstein, P.; Arneth, A.; et al. Greening of the Earth and its drivers. Nat. Clim. Chang. 2016, 6, 791-795. [CrossRef]

14. Kovacic, Z.; Salazar, O.V. The lose-lose predicament of deforestation through subsistence farming: Unpacking agricultural expansion in the Ecuadorian Amazon. J. Rural Stud. 2017, 51, 105-114. [CrossRef]

15. Feldpausch, T.R.; Phillips, O.L.; Brienen, R.J.W.; Gloor, E.; Lloyd, J.; Lopez-Gonzalez, G.; Monteagudo-Mendoza, A.; Malhi, Y.; Alarcón, A.; Dávila, E.Á.; et al. Amazon forest response to repeated droughts. Glob. Biogeochem. Cycles 2016, 30, 964-982. [CrossRef]

16. McPherson, E.G.; Nowak, D.; Heisler, G.; Grimmond, C.; Souch, C.; Grant, R.; Rowntree, R. Quantifying urban forest structure, function, and value: The Chicago Urban Forest Climate Project. Urban Ecosyst. 1997, 1, 49-61. [CrossRef]

17. Zak, M.; Cabido, M.; Cáceres, D.; Díaz, S. What Drives Accelerated Land Cover Change in Central Argentina? Synergistic Consequences of Climatic, Socioeconomic, and Technological Factors. Environ. Manag. 2008, 42, 181-189. [CrossRef]

18. Yang, J.; Gong, P.; Fu, R.; Zhang, M.; Chen, J.; Liang, S.; Xu, B.; Shi, J.; Dickinson, R.E. The role of satellite remote sensing in climate change studies. Nat. Clim. Chang. 2013, 3, 875-883. [CrossRef]

19. Pérez-Hoyos, A.; Rembold, F.; Kerdiles, H.; Gallego, J. Comparison of Global Land Cover Datasets for Cropland Monitoring. Remote Sens. 2017, 9, 1118. [CrossRef]

20. Fermi, V.E. Identifying and quantifying uncertainty and spatial disagreement in the comparison of Global Land Cover for different applications. Glob. Chang. Biol. 2008, 14, 1057-1075. [CrossRef]

21. Townshend, J.R.; Masek, J.G.; Huang, C.; Vermote, E.F.; Gao, F.; Channan, S.; Sexton, J.O.; Feng, M.; Narasimhan, R.; Kim, D.; et al. Global characterization and monitoring of forest cover using Landsat data: Opportunities and challenges. Int. J. Digit. Earth 2012, 5, 373-397. [CrossRef]

22. Qiu, B.; Chen, G.; Tang, Z.; Lu, D.; Wang, Z.; Chen, C. Assessing the Three-North Shelter Forest Program in China by a novel framework for characterizing vegetation changes. ISPRS J. Photogramm. Remote Sens. 2017, 133, 75-88. [CrossRef]

23. Keenan, R.J.; Reams, G.A.; Achard, F.; De Freitas, J.V.; Grainger, A.; Lindquist, E. Dynamics of global forest area: Results from the FAO Global Forest Resources Assessment 2015. For. Ecol. Manag. 2015, 352, 9-20. [CrossRef]

24. Zeng, Z.; Estes, L.; Ziegler, A.D.; Chen, A.; Searchinger, T.; Hua, F.; Guan, K.; Jintrawet, A.; Wood, E.F. Highland cropland expansion and forest loss in Southeast Asia in the twenty-first century. Nat. Geosci. 2018, 11, 556-562. [CrossRef]

25. Gardner, T.A.; Barlow, J.; Chazdon, R.; Ewers, R.M.; Harvey, C.A.; Peres, C.A.; Sodhi, N.S. Prospects for tropicalal forest biodiversity in a human-modified world. Ecol. Lett. 2009, 12, 561-582. [CrossRef]

26. Hansen, M.; DeFries, R.S. Detecting Long-term Global Forest Change Using Continuous Fields of Tree-Cover Maps from 8-km Advanced Very High Resolution Radiometer (AVHRR) Data for the Years 1982-99. Ecosystems 2004, 7, 695-716. [CrossRef]

27. Song, X.-P.; Hansen, M.C.; Stehman, S.V.; Potapov, P.V.; Tyukavina, A.; Vermote, E.F.; Townshend, J.R. Global land change from 1982 to 2016. Nat. Cell Biol. 2018, 560, 639-643. [CrossRef] 
28. Hansen, M.C.; Potapov, P.V.; Moore, R.; Hancher, M.; Turubanova, S.A.; Tyukavina, A.; Thau, D.; Stehman, S.V.; Goetz, S.J.; Kommareddy, A.; et al. High-Resolution Global Maps of 21st-Century Forest Cover Change. Science 2013, 342, 850-853. [CrossRef]

29. FAO. Global Forest Resources Assessments 2000; FAO Forestry Paper 140; The Food and Agricultural Organization of the United Nations: Rome, Italy, 2001.

30. FAO. Global Forest Resources Assessments 2010; FAO Forestry Paper 163; The Food and Agricultural Organization of the United Nations: Rome, Italy, 2010.

31. FAO. Global Forest Resources Assessments 2015; FAO Forestry Paper 1; The Food and Agricultural Organization of the United Nations: Rome, Italy, 2015.

32. Ordway, E.M.; Asner, G.P.; Lambin, E.F. Deforestation risk due to commodity crop expansion in sub-Saharan Africa Deforestation risk due to commodity crop expansion in sub-Saharan Africa. Environ. Res. Lett. 2017, 12, 044015. [CrossRef]

33. Qin, Y.; Xiao, X.; Dong, J.; Zhang, Y.; Wu, X.; Shimabukuro, Y.; Arai, E.; Biradar, C.; Wang, J.; Zou, Z.; et al. Improved estimates of forest cover and loss in the Brazilian Amazon in 2000-2017. Nat. Sustain. 2019, 2, 764-772. [CrossRef]

34. Gibbs, H.K.; Ruesch, A.S.; Achard, F.; Clayton, M.K.; Holmgren, P.; Ramankutty, N.; Foley, J.A. Tropical forests were the primary sources of new agricultural land in the 1980s and 1990s. Proc. Natl. Acad. Sci. USA 2010, 107, 16732-16737. [CrossRef]

35. Song, X.; Hansen, M.C.; Stephen, V.; Peter, V.; Tyukavina, A.; Vermote, E.F.; Townshend, J.R. The Vegetation Continuous Fields. 2018. Available online: https://glad.umd.edu/dataset/long-term-global-land-change (accessed on 28 June 2019).

36. Hansen, M.C.; Potapov, P.V.; Moore, R.; Hancher, M.; Turubanova, S.A.; Tyukavina, A.; Thau, D.; Stehman, S.V.; Goetz, S.J.; Loveland, T.R.; et al. Global Forest Change 2000-2017 Data, Version 1.5. 2013. Available online: https://earthenginepartners.appspot.com/science-2013-global-forest/download_v1.5.html (accessed on 28 June 2019).

37. Terra and Aqua combined Moderate Resolution Imaging Spectroradiometer Land Cover Climate Modeling Grid (MCD12C1). Available online: https://pdaac.usgs.gov/products/mcd12c1v006/ (accessed on 3 July 2019).

38. Sulla-menashe, D.; Friedl, M.A. User Guide to Collection 6 MODIS Land Cover (MCD12Q1 and MCD12C1) Product; USGS: Reston, VA, USA, 2018; pp. 1-18.

39. The Europe Space Agency (ESA). Land Cover Project of the Climate Change Initiative (CCI-LC) Data. Available online: https://www.esa-landcover-cci.org/?q=node/1 (accessed on 3 July 2019).

40. Bontemps, S.; Herold, M.; Kooistra, L.; Van Groenestijn, A.; Hartley, A.; Arino, O.; Moreau, I.; Defourny, P. Revisiting land cover observation to address the needs of the climate modeling community. Biogeosciences 2012, 9, 2145-2157. [CrossRef]

41. Hurtt, G.C.; Chini, L.; Sahajpal, R.; Frolking, S.; Bodirsky, B.L.; Calvin, K.; Doelman, J.C.; Fisk, J.; Fujimori, S.; Goldewijk, K.K.; et al. Harmonization of Global Land-Use Change and Management for the Period 850-2100 (LUH2) for CMIP6. Geosci. Model Dev. Discuss. 2020, 2020, 1-65. [CrossRef]

42. Global Ecology Laboratory, University of Maryland. The New Generation of Land-Use Harmonization (LUH2). Available online: https://www.wcrp-climate.org/wgcm-cmip/wgcm-LUH2 (accessed on 28 June 2019).

43. Olofsson, P.; Stehman, S.V.; Woodcock, C.E.; Sulla-Menashe, D.; Sibley, A.M.; Newell, J.D.; Friedl, M.A.; Herold, M. A global land-cover validation data set, part I: Fundamental design principles. Int. J. Remote Sens. 2012, 33, 5768-5788. [CrossRef]

44. Pengra, B.; Long, J.; Dahal, D.; Stehman, S.V.; Loveland, T.R. A global reference database from very high resolution commercial satellite data and methodology for application to Landsat derived $30 \mathrm{~m}$ continuous field tree cover data. Remote Sens. Environ. 2015, 165, 234-248. [CrossRef]

45. Hansen, M.C.; Stehman, S.V.; Potapov, P.V. Quantification of global gross forest cover loss. Proc. Natl. Acad. Sci. USA 2010, 107, 8650-8655. [CrossRef]

46. Chazdon, R.L.; Brancalion, P.H.S.; Laestadius, L.; Bennett-Curry, A.; Buckingham, K.; Kumar, C.; Moll-Rocek, J.; Vieira, I.C.G.; Wilson, S.J. When is a forest a forest? Forest concepts and definitions in the era of forest and landscape restoration. Ambio 2016, 45, 538-550. [CrossRef] [PubMed] 
47. Lesiv, M.; Moltchanova, E.; Schepaschenko, D.; See, L.; Shvidenko, A.; Comber, A.; Fritz, S. Comparison of data fusion methods using crowd sourced data in creating a hybrid forest cover map. Remote Sens. 2016, 8, 261. [CrossRef]

48. Schepaschenko, D.; See, L.; Lesiv, M.; McCallum, I.; Fritz, S.; Salk, C.; Moltchanova, E.; Perger, C.; Shchepashchenko, M.; Shvidenko, A.; et al. Development of a global hybrid forest mask through the synergy of remote sensing, crowdsourcing and FAO statistics. Remote Sens. Environ. 2015, 162, 208-220. [CrossRef]

Publisher's Note: MDPI stays neutral with regard to jurisdictional claims in published maps and institutional affiliations.

(C) 2020 by the authors. Licensee MDPI, Basel, Switzerland. This article is an open access article distributed under the terms and conditions of the Creative Commons Attribution (CC BY) license (http://creativecommons.org/licenses/by/4.0/). 